\section{Influence of Cusp Inclination and Type of Retention on Fracture Load of Implant-Supported Crowns}

Cibele Oliveira de Melo Rocha, Diogo Longhini, Rodrigo de Paula Pereira, João Neudenir Arioli Filho
Department of Dental Materials and Prosthodontics, Araraquara Dental School, UNESP Universidade Estadual Paulista, Araraquara, SP, Brazil

Correspondence: Cibele Oliveira de Melo Rocha, Rua Humaitá, 1680, 14801-903 Araraquara, SP, Brasil. Tel: +55-16-3301-6406. e-mail: cibeleomr@hotmail.com
There are few informations about the influence of cusp inclination on the fracture strength of implant-supported crowns. The study aimed to evaluate the influence of cusp inclination and retention type on fracture load in implant-supported metal-ceramic single crowns. Sixty crowns were made, classified as cemented and screw-retained with screw access hole $(\mathrm{SAH})$ sealed or not. Standard $\left(33^{\circ}\right)$ and reduced $\left(20^{\circ}\right)$ cusp inclinations were tested for each group $(n=10)$. To support crowns of a mandibular second molar, analogs of external hexagon implants 5.0 were used. The fracture load was measured in a universal testing machine EMIC DL2000 (10 kN load cell; $0.5 \mathrm{~mm} / \mathrm{min}$ ). Two-way ANOVA (retention and cusp inclination) followed by post hoc Tukey's honest significant difference test was used for the statistical analyses $(\alpha=0.05)$. Crowns with reduced cusp inclination exhibited significantly higher fracture load $(p<0.01)$ than crowns with standard cusp inclination. Cemented crowns showed significantly higher fracture load $(p<0.01)$ than screw-retained crowns. The interaction among these factors was not significant $(p>0.05)$ for the fracture load. The sealing of SAH did not influence the fracture load of screw-retained crowns ( $p>0.05$ ). In conclusion, fracture load of implant-supported metal-ceramic crowns was influenced by retention and cusp inclination, and there was no influence of the sealing of SAH.
Key Words: dental prosthesis, implant-supported crowns, material resistance.

\section{Introduction}

Implant-supported metal-ceramic crowns are often used in the treatment of partially edentulous patients, and such crowns may be cement- or screw-retained (1-4). The cemented prostheses have some advantages compared to the screw-retained, including higher fracture strength, passive fit, simplified restorative procedures and better aesthetics due to the absence of screw access hole (SAH) $(4,5)$. Nevertheless, removing the cemented crown is difficult without damaging the crown structure. Thus, removing procedure is the main advantage of screwretained crowns $(1-4,6)$, allowing re-tightening of the screw and easy removal of the crown for extraoral repairs and hygiene control $(2,3,5,7)$.

Several studies report lower fracture strength values for the screw-retained crowns $(1,2,4,5,7,8-11)$. This is explained by the presence of $\mathrm{SAH}$ that disrupts the structural continuity of the veneer porcelain $(2,4)$. Influence of other factors on the fracture strength of implant-supported prostheses has been investigated, like the SAH location (4), sealing the SAH (11), wall material of the SAH (metal or porcelain) (5), narrowing of occlusal platform (12) and type of the cement (13). However, the studies showed that these factors did not have any influence on the fracture strength values of crowns $(4,5,12,13)$.

For implant-supported crowns, fracture commonly begins on the occlusal surface and the stress is related to the complexity of occlusal restorations (14). In posterior natural teeth, the steep cusp inclination is a concern and a predisposing factor for fracture incidence (15). Although there are differences between natural and artificial crowns in relation to the internal structure and material composition (16), it is believed that this fact may also affect the fracture strength of prosthetic crowns $(14,17)$. The literature shows some studies focused on the importance of the occlusal design on the implant overloading (18-22), stress distribution in crowns (14) and fracture of natural teeth $(15,16)$. However, further studies are required to understand the influence of cusp inclination exclusively on the fracture strength of these crowns.

Thus, the aim of this study was to evaluate the influence of the cusp inclination and retention type on the fracture load of metal-ceramic implant-supported single crowns. The tested hypothesis was that there would be no difference between screw-retained (SAH sealed or not) and cemented crowns, as well as between cusp inclinations on the fracture load.

\section{Material and Methods}

Metal-ceramic crowns were divided into six groups according cusp inclination and retention type (Table 
1). A natural mandibular second molar was used for fabrication of crowns with standard $33^{\circ}$ cusp inclination $(\mathrm{SCl})$, confirmed by a protractor overlapping the digitized image of the tooth. The impression of this natural tooth crown was made with condensation silicone (Zetalabor; Zhermack SPA, Badia Polesine, R0, Italy) and the mold filled with molten wax. For fabrication of crowns with reduced cusp inclination $(\mathrm{RCI})$, the wax pattern cusp was reduced to $20^{\circ}$ inclination, confirmed by a protractor overlapping the real image of the tooth. The waxed crowns were fixed on UCLA prosthetic component (UCLA Abutment; Biomet 3i, Palm Beach Gardens, FL, USA) and screwed on the analog of external hexagon implant with a $5.0 \mathrm{~mm}$ diameter (Biomet 3i) positioned in a metal device (Fig. 1).

To standardize the final anatomy of the restorations and the thickness of the ceramic surface, indexes (to SCl and $\mathrm{RCl}$ ) of the waxed-up mandibular molar were made with silicone condensation (Zetalabor) and sectioned in half from mesiodistal and from buccolingual. To make the metal framework of all screw-retained restorations, the waxed-up mandibular molar was cut down simulating

Table 1. Experimental groups $(\mathrm{n}=10)$

\begin{tabular}{ll}
\hline Groups & $\begin{array}{l}\text { Type of retention and cusp inclination } \\
\text { of the metal-ceramic crowns }\end{array}$ \\
\hline SNS/20 & $\begin{array}{l}\text { Screw-retained with the screw } \\
\text { access hole not sealed }\end{array}$ \\
SS/20 & Screw-retained with the screw access hole sealed \\
C/20 & Cemented \\
SNS/33 & $\begin{array}{l}\text { Screw-retained with the screw } \\
\text { access hole not sealed }\end{array}$ \\
SS/33 & Screw-retained with the screw access hole sealed \\
C/33 & Cemented \\
\hline
\end{tabular}

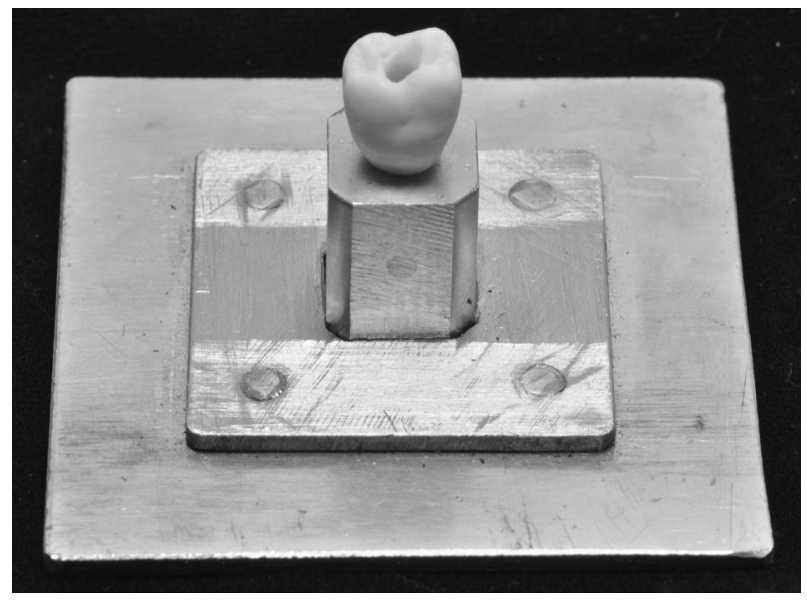

Figure 1. Metal device containing the waxed crown screwed on the analog of the implant. a metal framework on which a ceramic layer around 2 $\mathrm{mm}$ thick is applied to improve aesthetics (5). Silicone condensation indexes (Zetalabor) were made and sectioned as previously described. For cemented crowns, the waxedup metal framework to screw-retained restoration was cut down simulating an abutment preparation with total taper around $6^{\circ}$ and $5.0 \mathrm{~mm}$ high regarding the adequate thickness to the metal copings and the ceramic surface. Other silicone indexes (Zetalabor) were made as previously described to standardize the framework of all abutments of the cement crowns.

Sixty analogs with a $5.0 \mathrm{~mm}$ platform diameter and 10.0 $\mathrm{mm}$ long were screwed at the center of a metallic device, adapted on a rigid PVC ring to maintain the analogs inside the rings (Fig. 2). This device allows the insertion of the epoxy resin (Araldite GY1109; Huntsman, São Paulo, SP, Brazil) in the analogs inside the PVC ring. A torque of 32 N.cm was used on the crowns of the screw-retained groups and abutments of the cemented groups .

SAH of the SS/20 and SS/33 groups were filled with cotton (Soft Cotton, Piracicaba, SP, Brazil). Silane agent (Silane; Dentsply, Petropolis, RJ, Brazil) was applied. After $1 \mathrm{~min}$, a thin layer of adhesive system (Scotchbond Multi Purpose Plus; 3M ESPE, St. Paul, MN, USA) was also applied and activated for $20 \mathrm{~s}$ by a visible light unit (Radii Cal; SDI, São Paulo, SP, Brazil) with a light intensity of 1200 $\mathrm{mW} / \mathrm{cm}^{2}$. The composite resin (Filtek P60; 3M ESPE) was inserted in three layers, each activated for $40 \mathrm{~s}$ with the same light unit.

In the $\mathrm{C} / 20$ and $\mathrm{C} / 33$ groups, the $\mathrm{SAH}$ of the abutments were filled with cotton to isolate the screw during the filling of the SAH. The cementation was performed with a self-adhesive resin cement (Rely X U200; 3M ESPE) mixed according to the manufacturer's recommendations.

The fracture load static test was performed in a universal

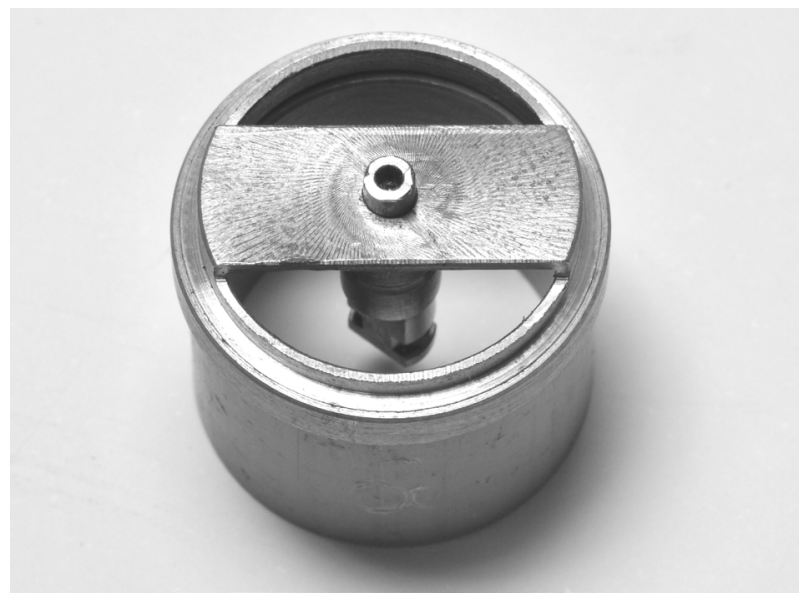

Figure 2. Analog screwed in the center of a metallic device, which was adapted on a rigid PVC ring to maintain the analogs inside the rings. 
testing machine (DL 2000; EMIC, São José dos Pinhais, $\mathrm{PR}$, Brazil) with a 10-kN load cell and a cross speed of 0.5 $\mathrm{mm} / \mathrm{min}$ until porcelain failure, and the maximum values recorded in Newton (N). A stainless steel device with a $6.0 \mathrm{~mm}$ diameter ball tip was used to apply compressive vertical force simultaneously on the buccal and lingual cusps of the restoration.

Statistical analyses were performed using the SPSS 19.0 (Statistical Package for Statistical Science Inc, Chicago, IL, USA). Normality was checked with the Shapiro-Wilk test and homogeneity of variance with the Levene test to obtain maximum fracture resistance data (N). Two-way ANOVA (retention and cusp inclination) followed by post hoc Tukey's honest significant difference test $(\alpha=0.05)$ was used to detect whether there was a significant effect of the factors, type of retention (screw-retained crowns and cemented crowns) and cusp inclination ( $\mathrm{SCl}$ and $\mathrm{RCl}$ ) on the fracture load of the different experimental groups.

The failure mode of the specimens was evaluated by a scanning electron microscope (SEM) (JEOL - JSM 6510; Jeol, Tokyo, Japan) and was classified as adhesive (failure at the ceramic-metal framework interface), cohesive (failure within the ceramic), or a combination (areas of cohesive $\vec{s}$ and adhesive failure).

\section{Results}

Two-way analysis of variance to fracture load was significant for inclination cusp $(p<0.01)$ and retention type $(p<0.01)$ but not for the interaction between these factors $(p>0.05) . \mathrm{RCl}$ showed statistically higher fracture load $(2476.2 \pm 823.7 \mathrm{~N})$ than $\mathrm{SCl}$ crowns $(1203.9 \pm 752.5 \mathrm{~N})$ and cemented crowns showed statistically higher fracture load

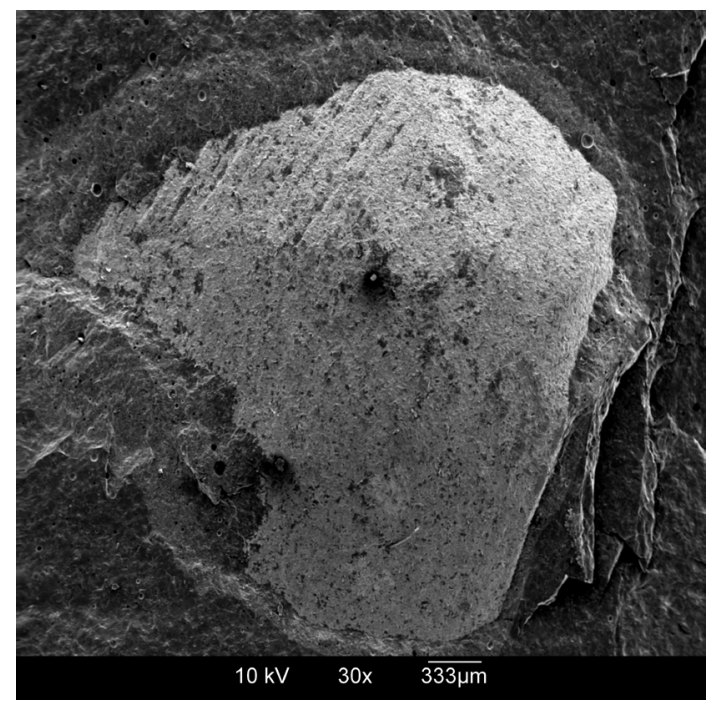

Figure 3. SEM image at 30x magnification showing mixed failure (adhesive and cohesive).
$(2445.6 \pm 1122.4 \mathrm{~N})$ than the screw-retained crowns with sealed SAH $(1695.9 \pm 890.9)$ and not sealed $(1378.7 \pm 701.9 \mathrm{~N})$.

Whatever the cusp inclination and type of retention, SEM analysis showed that all specimens were affected similarly with adhesive failure between ceramic and metal, and cohesive failures in ceramic (Fig. 3). Most of the crowns showed occlusal surface fractures, involving one or more surrounding surfaces (Fig. 4). In these conditions, the compressive force applied with the sphere on the crowns may cause external displacement of the cusps.

\section{Discussion}

Steep cusp inclination and deep grooves are predisposing factors to fracture incidence in posterior natural teeth (15). In the present study, the cusp inclination influenced the mechanical behavior of the prosthetic metal-ceramic crowns, with higher values of fracture load of $\mathrm{RCl}$ crowns compared to $\mathrm{SCl}$ crowns $(p<0.05)$. Similar results were found for veneered zirconia crowns with steep inclination, especially in combination with sharp curvatures, increasing chipping rates and decreasing fracture load (17). In crowns with a steeper cusp inclination, increased lateral forces are produced when vertical loads are applied on occlusal surfaces $(20,21)$. This is especially important to implant-supported crowns, because osseointegrated implants do not have micromovement associated with force distribution, as occurs for natural teeth due to the periodontal ligament (21).

In general, there is influence of cusp inclination in implant overloading (18-22), which is one of the main causes of biological failure at bone-implant interface (BII) (22). BII stress increases with high cusp inclination (18), which may result in damages to bone implant contact (22). Besides the biological complications, technical problems

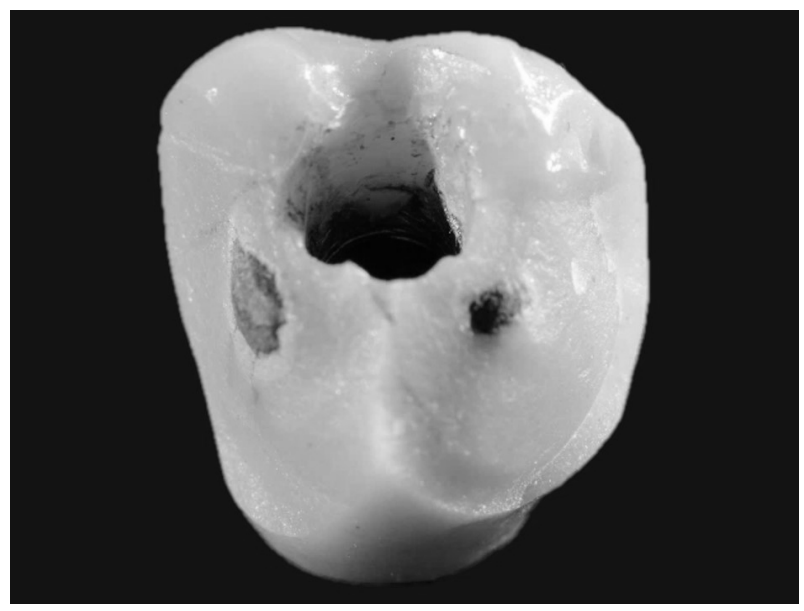

Figure 4. Fracture pattern involving the occlusal and surrounding surfaces of the crown. 
may also be associated with the cusp inclination design, which should be based not only on the clinical requirements as antagonist and adjacent dentition, but also on the biomechanical knowledge of the dentist. Thus, further studies are required to assess the effects of this factor on the fracture strength of implant-supported crowns to establish parameters for the restoration designs, in an attempt to reduce technical complications arising from a certain occlusal anatomy.

As regards the retention type, higher values of fracture load for cemented crowns compared to screw-retained were shown in the present study, agreeing with the findings of other authors $(2,4,5,8,9,11)$. In a 15 -year clinical study, porcelain fracture was significantly more frequent in screwretained crowns while cemented crowns had better clinical and biological results in relation to marginal bone loss and gingival index (8). Conversely, more serious biological complications were found in cemented prostheses, as implant failures and bone resorptions were greater than $2 \mathrm{~mm}$ (9). Although none of the two retention types was clearly advantageous, the reversibility of screw-retained crowns allows easier treatment of technical and biological complications (9).

Some authors explain that SAH in screw-retained crowns may weaken the porcelain due to structural discontinuity $(1,2,4,23)$. SAH might interfere with the occlusion $(2,3,7,10,23)$, generating unstable contacts $(10,23)$ and impairing vertical and axial loads (2). It is supposed that SAH adhesive sealing with composite resin can stabilize the porcelain layer $(2,6)$, but this is still controversial. In a recent study, it was found that SAH sealing did not influence the fracture resistance of the screw-retained (11). In the present study, there were no significant statistical differences for fracture load values of porcelain with SAH sealed or not. SAH sealing was not able to stabilize the porcelain layer and increase the fracture strength of screw-retained crowns. In clinical practice, SAHs are not left unsealed, necessary to keep the occlusal morphology, esthetics and function of the restoration (11). However, most studies have used unsealed $\mathrm{SAH}$, due to the absence of a sealing protocol $(2,6,7,13)$.

Regardless of the higher fracture strength found in cemented crowns compared to screw-retained and to $\mathrm{RCl}$ compared to $\mathrm{SCl}$, all groups showed higher fracture strength than the maximum bite force in the molar region, which ranged from 300 to $800 \mathrm{~N}$ (7). However, in relation to cusp inclination, safer rehabilitation can be obtained with $\mathrm{RCl}$, due the diminished lateral forces $(20,21)$. It is important to emphasize that occlusal aesthetics can be achieved both with a $20^{\circ}$ cusp inclination as well as with a $33^{\circ}$ cusp inclination. The reduction of cusp inclination is not a limiting factor to the optimum final result of the restoration.
As a limitation, the study was performed only in single load testing of failure, which can be difficult relative to clinical conditions. Further studies about implantsupported crowns (cemented or screw-retained, $\mathrm{RCl}$ or $\mathrm{SCl}$ ) under fatigue protocols and eventually, controlled clinical trials, could help in understanding the intraoral behavior of these restorations.

In conclusion, fracture load of implant-supported metal-ceramic crowns was influenced by retention and cusp inclination, and no influence was shown by sealing the SAH.

\section{Resumo}

Existem poucas informações sobre a influência da inclinação de cúspide na resistência à fratura de coroas implantossuportadas. 0 objetivo do estudo foi avaliar a influência da inclinação de cúspide e do tipo de retenção na carga de fratura de coroas unitárias metalocerâmicas implantossuportadas. Sessenta coroas foram confeccionadas, classificadas como cimentadas e parafusadas com orifício de acesso ao parafuso selado ou não. Cúspides com inclinação padrão $\left(33^{\circ}\right)$ e reduzida $\left(20^{\circ}\right)$ foram testadas para cada grupo $(n=10)$. Para suportar as coroas de um segundo molar inferior, análogos de implante hexágono externo 5.0 foram utilizados. A carga de fratura foi mensurada em máquina de ensaios universais EMIC DL2000 (célula de carga de $10 \mathrm{kN} ; 0,5 \mathrm{~mm} / \mathrm{min}$ ). ANOVA dois fatores (retenção e inclinação da cúspide) seguido do pós-teste de Tukey da diferença honestamente significativa foi utilizada para análise estatística $(\alpha=0,05)$. Coroas com inclinação de cúspide reduzida exibiram carga de fratura significativamente maior $(p>0,05)$ que coroas com cúspides de inclinação padrão. Coroas cimentadas apresentaram carga de fratura significativamente maior $(p<0,01)$ que coroas parafusadas. A interação entre os dois fatores não foi significante $(p>0,05)$ para a carga de fratura. 0 selamento do orifício de acesso ao parafuso não influenciou a carga de fratura das coroas parafusadas $(p>0,05)$. Concluindo, a carga de fratura de coroas metalocerâmicas implantossuportadas foi influenciada pelo tipo de retenção e inclinação da cúspide, e não houve influência do selamento do orifício de acesso ao parafuso

\section{Acknowledgements}

The authors declare no competing financial interests. This study was supported by FAPESP (Fundação de Amparo à Pesquisa do Estado de São Paulo), grant \#2013/01119-1.

\section{References}

1. Hebel KS, Gajjar RC. Cement-retained versus screw-retained implant restorations: achieving optimal occlusion and esthetics in implant dentistry. J Prosthet Dent 1997;77:28-35.

2. Karl M, Graef F, Taylor TD, Heckmann SM. In vitro effect of load cycling on metal-ceramic cement- and screw-retained implant restorations. J Prosthet Dent 2007;97:137-140.

3. Michalakis KX, Hirayama H, Garefis PD. Cement-retained versus screwretained implant restorations: a critical review. Int J Oral Maxillofac Implants 2003;18:719-728.

4. Torrado E, Ercoli C, Mardini MA, Graser GN, Tallents RH, Cordaro L. A comparison of the porcelain fracture resistance of screw-retained and cement-retained implant-supported metal-ceramic crowns. J Prosthet Dent 2004;91:532-537.

5. Oliveira JLG, Martins LM, Sanada J, Oliveira PCG, Valle AL. The effect of framework design on fracture resistance of metal-ceramic implantsupported single crowns. Int J Prosthodont 2010;23:350-352.

6. Karl M, Graef F, Wichmann MG, Heckmann SM. The effect of load cycling on metal ceramic screw-retained implant restorations with unrestored and restored screw access holes. J Prosthet Dent 
2008;99:19-24.

7. Al-Omari WM, Shadid R, Abu-Naba'a L, Masoud BE. Porcelain fracture resistance of screw-retained, cement-retained, and screw-cementretained implant-supported metal ceramic posterior crowns. J Prosthodont 2010;19:263-273.

8. Nissan J, Narobai D, Gross 0, Ghelfan 0, Chaushu G. Long-term outcome of cemented versus screw-retained implant-supported partial restorations. Int J Oral Maxillofac Implants 2011;26:1102-1107.

9. Sailer I, Mühlemann $\mathrm{S}$, Zwahlen $\mathrm{M}$, Hämmerle $\mathrm{CH}$, Schneider D. Cemented and screw-retained implant reconstructions: a systematic review of survival and complication rates. Clin Oral Implants Res 2012;23:163-201.

10. Zarone F, Sorrentino R, Traini T, Di lorio D, Caputi S. Fracture resistance of implant-supported screw- versus cement-retained porcelain fused to metal single crowns: SEM fractographic analysis. Dent Mater 2007;23:296-301.

11. Pereira RP, Rocha COM, Reis JM, Arioli-Filho JN. Influence of sealing of the screw access hole on the fracture resistance of implant-supported restorations. Braz Dent J 2016;27:148-152.

12. Singer A, Serfaty V: Cement-retained implant-supported fixed partial dentures: a 6-month to 3-year follow-up. Int J Oral Maxillofac Implants 1996;11:645-649.

13. Shadid RM, Abu-Naba'a L, Al-Omari WM, Asfar KR, Masoud BME. Effect of an occlusal screw-access hole on the fracture resistance of permanently cemented implant crowns: a laboratory study. Int J Prosthodont 2011;24:267-269.

14. Sornsuwan T, Swain MV. Influence of occlusal geometry on ceramic crown fracture; role of cusp angle and fissure radius. J Mech Behav Biomed Mater 2011;4:1057-1066.
15. Khera SC, Carpenter CW, Vetter JD, Staley RN. Anatomy of cusps of posterior teeth and their fracture potential. J Prosthet Dent 1990;64:139-147.

16. Chai H. On crack growth in molar teeth from contact on the inclined occlusal surface. J Mech Behav Biomed Mater 2015;44:76-84.

17. Preis V, Dowerk $T$, Behr M, Kolbeck C, Rosentritt M. Influence of cusp inclination and curvature on the in vitro failure and fracture resistance of veneered zirconia crowns. Clin Oral Investig 2014;18:891-900.

18. Falcón-Antenucci RM, Pellizzer EP, de Carvalho PS, Goiato MC, Noritomi PY. Influence of cusp inclination on stress distribution in implant-supported prostheses. A three-dimensional finite element analysis. J Prosthodont 2010;19:381-386.

19. Weinberg LA. Therapeutic biomechanics concepts and clinical procedures to reduce implant loading. Part I. J Oral Implantol 2001;27:293-301.

20. Kaukinen JA, Edge MJ, Lang BR. The influence of occlusal design on simulated masticatory forces transferred to implant-retained prostheses and supporting bone. J Prosthet Dent 1996;76:50-55.

21. Weinberg LA. The biomechanics of force distribution in implantsupported prostheses. Int J Oral Maxillofac Implants 1993;8:19-31.

22. Rungsiyakull C, Rungsiyakull P, Li Q, Li W, Swain M. Effects of occlusal inclination and loading on mandibular bone remodeling: a finite element study. Int J Oral Maxillofac Implants 2011;26:527-537.

23. Vigolo P, Mutinelli S, Givani A, Stellini E. Cemented versus screwretained implant-supported single-tooth crowns: a 10-year randomised controlled trial. Eur J Oral Implantol 2012;5:355-364.

Received May 3, 2016 Accepted November 25, 2016 